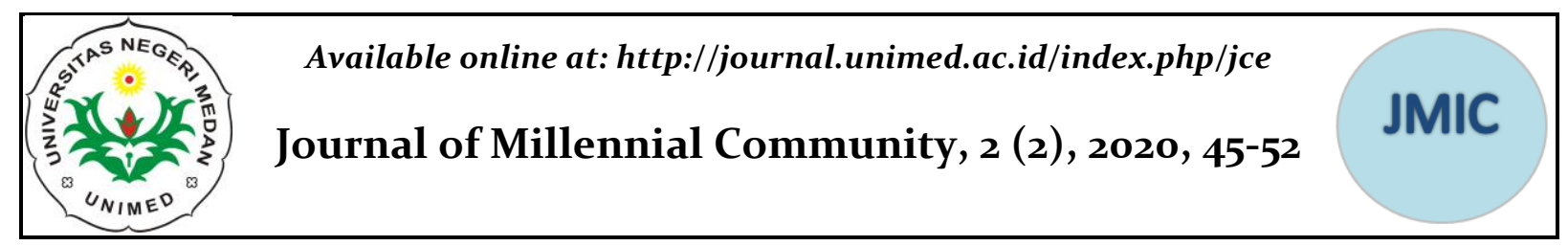

\title{
Pengembangan Metode Pembelajaran Inovatif Bagi Tutor Keaksaraan Di Kabupaten Wonogiri
}

\author{
Tristanti $^{1}$, Sujarwo ${ }^{2}$, RB Suharta ${ }^{3}$ \\ ${ }^{123}$ Pendidikan Luar Sekolah, Universitas Negeri Yogyakarta \\ *Email: tristanti@uny.ac.id
}

\begin{abstract}
Abstrak
Kegiatan pelatihan pembelajaran inovatif bagi tutor keaksaraan merupakan kegiatan untuk menumbuhkan kesadaran tutor dalam pengemabnagan metode pembelajaran. Kegiatan ini bertujuan untuk 1) memberikan pemahaman kepada tutor keaksaraan akan pentingnya pembelajaran inovatif, 2) memberikan pengetahuan dan keterampilan kepada tutor kekasaraan dalam menerapkan metode pembelajaran inovatif. Pelaksanaan kegiatan pemberdayaan diawali dengan analisis kebutuhan, penetapan materi, pelaksanaan, dan evaluasi terhadap 25 orang yutor keaksaraan. Metode kegiatan meliputi ceramah, tanya jawab dan diskusi Hasil kegiatan menunjukkan bahwa 1) tutor keaksaraan memiliki pengetahuan dalam pembelajaran inovatif yaitu metode PAKEM dan pembelajaran berpusat pada warga belajar, 2) tutor keaksaraan mampu mempraktekkan metode pembelajaran inovatif dalam pembelajaran di masyarakat.
\end{abstract}

Kata Kunci: pembelajaran inovatif, tutor, kekasaraan

\section{Development of Innovative Learning Methods for Literacy Tutors in Kabupaten Wonogiri}

\begin{abstract}
Innovative learning training activities for literacy tutors were activities to raise tutor awareness in developing learning methods. This activity aims to 1) provide literacy tutors with an understanding of the importance of innovative learning, 2) provide literacy tutors with knowledge and skills in applying innovative learning methods. The implementation of empowerment activities begins with a needs analysis, determination of materials, implementation, and evaluation of 25 literacy leaders. Activity methods include lectures, question and answer and discussion. The results of the activity show that 1) literacy tutors have knowledge in innovative learning, namely the PAKEM method and citizen-centered learning, 2) literacy tutors are able to practice innovative learning methods in learning in society.
\end{abstract}

Keywords: innovative learning, tutors, literacy

\section{PENDAHULUAN}

Setiap kehidupan manusia selalu dilengkapi dengan kegiatan belajar. Belajar dapat dilakukan di mana saja dan kapan saja serta dengan siapa saja. Namun demikian kegiatan belajar yang kurang bermakna bagi peserta belajar maka pengetahuan yang diperoleh tidak memiliki makna yang berarti bagi kehidupannya. Pembelajaran adalah proses komunikasi dan interaksi antara warga belajar dengan pendidik yang diselenggarakan untuk mencapai tujuan belajar yang dibutuhkan. Oleh karena itu pendidik harus memahami apa yang menjadi kebutuhan peserta didik, agar apa yang disampaikan dapat diterima dan diaplikasikan dalam kehidupannya. Sebagai contoh dalam hal pembelajaran keaksaraan. 
Pembelajaran keaksaraan merupakan proses interaksi antara pendidik dan warga belajar buta aksara untuk mencapai hasil yang maksimal yaitu warga belajar dapat bebas buta aksara. Tentunya harus dilakukan dengan berbagai cara atau metode yang sesuai agar materi dapat tersampaikan.

Wonogiri merupakan salah satu kabupaten di Jawa Tengah yang memiliki tingkat buta aksara cukup tinggi. Kabupaten Wonogiri menyandang peringkat ke delapan se-jawa tengah dengan tingkat buta aksara merata di seluruh kecamatan. Lebih lanjut dijelaskan oleh Kabid Pendidikan Non Formal Indonesia (PNFI) bahwa Penyandang buta aksara di Kabupaten Wonogiri tersebar di 25 kecamatan. Menurut data tahun 2015 jumlah total adalah 9.847 orang, tertinggi di Kecamatan Kismantoro dengan 826 orang, disusul Kecamatan Eromoko sebanyak 766 orang peringkat ketiga adalah Kecamatan Pracimantoro dengan 545 orang (www.sorotwonogiri.com). Selama ini berbagai usaha telah diusahan oleh pemerintah untuk mengurangi jumlah buta aksara melalui berbagai kerja sama antar lembaga. Namun demikian pengurangan tersebut masih belum optimal. hal tersebut perlu diperhatikan bahwa tidak hanya pendidik dan peserta didik atau warga belajar yang menjadi faktor ketidakberhasilan dalam pembelajaran keaksaraan akan tetapi faktor lain yaitu faktor metode pembelajaran yang digunakan.

Metode pembelajaran merupakan komponen penting dalam pembelajaran karena berfungsi sebagai pengantar interaksi antara pendidik dengan peserta didik. Metode pembelajaran dapat dijelaskan lebih rinci adalah cara atau situasi yang digunakan atau dirancang oleh pendidik untuk peserta didik dalam proses pembelajaran sehingga materi yang disampaikan dapat diterima dengan mudah. Dalam hal ini, pendidik harus memiliki kreativitas dalam pengembangan metode pembelajaran. Pendidik dalam proses pembelajaran keaksaraan disebut sebagai tutor. Selama ini kegiatan pembelajaran keaksaraan yang dirancang oleh tutor masih berpedoman pada metode konvensional seperti sistem persekolahan. Hal tersebut dikarenakan tutor dalam pendidikan keaksaraan umumnya berasal dari bagian masyarakat tersebut, sehingga pengalaman akan pengembangan metode pembelajaran masih minim. Selain itu tutor keaksaraan hanya berpedoman pada buku panduan yang menjadi pegangan dalam menyampaikan materi. Padahal perlu diketahui bahwa sasaran dari kelompok keaksaraan adalah orang dewasa yang sudah memiliki banyak pengalaman dalam kehidupannya, sehingga perlu adanya metode-metode inovasi yang dapat memotivasi warga belajar untuk belajar keaksaraan. Tutor merupakan komponen penting dalam kegiatan pembelajaran. dala hal ini tutor harus mampu mengembangkan metode pembelajaran dengan baik. Kompetensi tutor meliputi: a) kompetensi andragogi, b) kepribadian, c) sosial, dan d) profesional. Untuk itu agar kinerja tutor lebih meningkat, maka perlu diketahui kebutuhan belajar tutor yang sesuai. Kebutuhan belajar bagi tutor diperlukan tutor untuk meningkatkan kompetensi dalam pembelajaran kesetaraan. Tutor sebagai pendidik dalam pendidikan non formal harus memiliki keterampilan dan sikap untuk menunjang penampilannya yaitu: a) Memiliki latar belakang pendidikan yang sesuai dengan bidang tugasnya; b) Memiliki kompetensi yang diperlukan sesuai dengan bidang tugasnya; c) Memiliki kesempatan untuk mengembangkan profesinya melalui berbagai diklat dan workshop.

Pentingnya pengembangan pada metode inovasi pembelajaran dikarenakan tiga alasan. Alasan yang pertama yaitu metode pembelajaran merupakan variabel manipulatif yang berarti tutor memiliki kebebasan untuk memilih dan menggunakan metode pembelajaran sesuai dengan karakterisitik warga belajar. Alasan kedua yaitu metode pembelajaran memiliki fungsi sebagai instrumen yang membantu warga belajar dalam memperoleh pengalaman warga belajar. Tingkat kesulitan materi dapat diatasi apabilan tutor mampu mengembangkan pembelajaran dengan metode yang menarik bagi warga belajar. Alasan yang terakhir yaitu pengembangan 
metode pembelajaran dalam konteks peningkatan mutu perolehan hasil belajar perlu diupayakan secara terus-menerus dan bersifat komprehensif karena proses pembelajaran merupakan faktor determinan terhadap mutu hasil belajar. Metode pembelajaran yaitu suatu cara / tindakan yang dirancang tutor, sehingga menimbulkan kegiatan belajar bagi para warga belajar dan juga warga belajar dapat mencerna bahan pembelajaran yang disampaikan tutor dengan mudah dan baik.

Metode pembelajaran yang akan digunakan dalam selama proses pembelajaran kekasaraan harus memenuhi kriteria: a) Pemilihan dan penetapan strategi dan metode harus berorientasi pada tujuan pembelajaran yang ingin dicapai, b) Memperhatikan materi (bahan belajar) yang akan disampaikan kepada warga belajar dengan berbagai karekteristiknya sebagai orang dewasa, c) Media belajar yang akan digunakan dalam proses pembelajaran, d) Tingkat kemampuan dan kemudahan warga belajar dalam menyerap dan memahami materi pembelajaran dan, e) Memperhatikan efektivitas, efisiensi, daya tarik media, dan iklim, suasana pembelajaran di kelompok belajar. Model pembelajaran inovatif adalah model pembelajaran yang memanfaatkan model-model pembelajaran mutakhir. Pembelajaran Inovatif diyakini mampu memfasilitasi siswa untuk mengembangkan kecakapan hidup dan siap terjun di masyarakat, karena pembelajaran inovatif mengandung prinsip-prinsip sebagai berikut: 1) Berpusat pada siswa, 2) Berbasis masalah, 3) Terintegrasi, 4) Berbasis masyarakat, 5) Memberikan pilihan, 6) Tersistem dan 7) Berkelanjutan.

Metode pembelajaran inovatif dapat berupa diskusi kelompok, pemecahan masalah, bersumber pada pengalaman dan kehidupan. Oleh karena itu kegiatan pengembagan metode pembelajaran inovasi bagi tutor keaksaraan dirasa sangat penting untuk dilakukan dalam mendukung program penuntasan buta aksara di kabupaten Wonogiri.

\section{METODE}

Metode yang digunakan adalah tindakan pelatihan dengan jumlah sasaran sebanyak 25 tutor di kabupaten Wonogiri. Dalam kegiatan pelatihan menekankan pada pembelajaran berorientasi pengalaman atau Page $\mid 47$ masalah dan berorientasi pada pembelajaran orang dewasa. Metode kegiatan yang diterapkan yaitu ceramah, tanya jawab dan praktek. Kegiatan pelatihan ini berlangsung selama 16 jam. Adapun langkah dalam pemecahan masalah adalah: a) Penentuan Kebutuhan, b) Penetapan Materi Pelatihan, c) Pelaksanaan Program, d) Evaluasi Pelaksanaan Program.

Evaluasi pelaksanaan program akan dilakukan secara langsung pada saat kegiatan yaitu kemampuan kelompok sasaran dalam mempraktekkan kegiatan outbound. Selain itu evaluasi juga dilakukan secara lisan melalui tanya jawab terkait kebermanfaatan dan kebermaknaan program pelatihan terhadap kelompok sasaran.

\section{HASIL DAN PEMBAHASAN}

Kegiatan pelatihan metode pembelajaran inovatif bagi tutor telah memberikan manfaat bagi kelompok sasaran berupa pengetahuan metode pembelajaran inovatif. Kegiatan pelatihan ini dilakukan melalui berbagai tahapan:

1. Melakukan Persiapan

Dalam tahap ini, tim pengabdi melakukan persiapan terkait administrasi persuratan. Kemudian dilanjutkan dengan koordinasi awal antara tim pengabdi dengan pihak Sanggar Kegiatan Belajar (SKB) Wonogiri dan perwakilan tutor Kabupaten Wonogiri. Koordinasi awal menghasilkan kesepakatan terkait waktu dan tempat pelaksanaan yaitu pada tanggal 25 dan 26 Oktober 2017 di aula SKB Wonogiri. Sebelum melaksanakan kegiatan pengabdian, tim pengabdi melakukan kegiatan penjajagan awal dari kemampuan peserta pelatihan melalui metode wawancara dan dokumentasi. Dari hasil observasi awal tersebut didapatkan informasi bahwa kemampuan tutor keaksaraan dalam pembelajaran masih rendah. Metode yang 
digunakan belum bervariatif masih terfokus pada pembelajaran klasikal yaitu ceramah.

\section{Melakukan Kegiatan Pelatihan}

Kegiatan pelatihan metode pembelajaran inovatif ditujukan bagi tutor keaksaraan agar memiliki kemampuan dalam pengembangan metode pembelajaran inovatif. Indikator keberhasilan dari kegiatan pelatihan ini adalah :

a. Tingkat kehadiran tutor dalam mengikuti kegiatan pelatihan adalah minimal $70 \%$.

b. Tutor memiliki kemampuan dalam memahami metode pembelajaran inovatif yang ditunjukkan dengan kemampuan dalam memecahkan permasalahan yang diberikan oleh pemateri.

c. Tutor mampu mempraktekkan metode pembelajaran inovatif dalam pembelajaran keaksaraan di masyarakat yang ditunjukkan dengan kegiatan praktek di masyarakat. Dalam hal ini pengabdi melakukan pendampingan untuk mengetahui aktifitas tutor dalam pengemabnagan metode pembelajaran. Metode yang digunakan yaitu pemanyauan melalui alat komunikasi (whatsap, sms).

Adapaun kegiatan pelatihan dilaksanakan dengan melalui tahapan:

\section{a. Pembukaan}

Kegiatan dimulai pada pukul o8.oo wib dan dibuka oleh kepala SKB Wonogiri. Kegiatan selanjutnya yaitu sambutan dari ketua tim pengabdi yang menyampaikan terkait maksud dan tujuan kegiatan pelatihan metode pembelajaran inovatif.

b. Inti pelaksanaan

Dalam kegiatan dilaksanakan oleh tim pengabdi dengan memberikan materi dengan tema Student Center Learning. Metode kegiatan yang digunakan yaitu ceramah dan tanya jawab. Materi yang disampaikan dengan metode ceramah dimulai dengan penekanan pada pentingnya metode pembelajaran inovatif dikarenakan perubahan yang meliputi perubahan paradigma, perubahan kompetensi, perubahan kurikulum, dan perubahan perilaku pembelajaran. Dijelaskan pula tentang proses pembelajaran bahwa pembelajaran itu berbeda dengan belajar mengajar. Jika dalam belajar mengajar hanya sebagai proses pemberian pengetahuan dari tutor kepada peserta didik, sedangkan pembelajaran adalah kegiatan interaksi antara tutor dan peserta didik sehingga terjadi kebermaknaan dalam diri peserta didik. Pemateri juga menyampaikan bahwa dalam pembelajaran harus menimbulkan kesan bagi peserta didik, sehingga peserta didik merasa nyaman dan termotivasi untuk selalu belajar. Lebih lanjut dijelaskan oleh pemateri untuk memudahkan dalam pembelajaran maka diharapkan tutor memahami tentang "PAKEM" yaitu Pembelajaran Aktif Kreatif Efektif dan Menyenangkan. Dalam hal ini peserta pelatihan belum pernah ada yang mengetahui konsep tersebut dan baru pertama kali mendengar istilah tersebut ketika pelatihan saat itu. Pembelajaran dengan PAKEM yaitu pembelajaran yang menantang warga belajar untuk belajar, mendorong warga belajar dalam menemukan ide, menyenangkan bagi warga belajar dalam mengikuti aktifitas belajar, pembelajaran memberikan pengalaman sukses bagi warga belajar dan mengembangkan kecakapan berpikir mahasiswa.

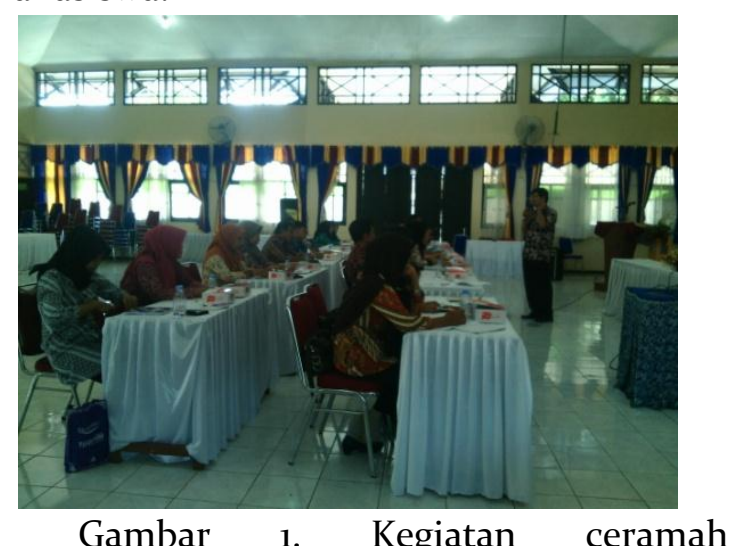

penyampaian materi

Selain metode ceramah pemateri juga menggunakan metode tanya jawab dalam hal pengalaman tutor dalam proses pembelajaran. Hal-hal yang menjadi tema diskusi yaitu: 
1. Lama menjadi tutor keaksaraan. Sebagian tutor ada yang menyebutkan sudah lama sekali yaitu sudah 10 tahun sebagai tutor dan sebagian lagi tergolong dalam tutor yang masih baru karena baru satu tahun menjadi tutor.

2. Proses pembelajaran keaksaraan. Beberapa tutor menjelaskan cara mengajar dengan cara melibatkan keterampilan sebagai perangsang warga belajar keaksaraan untuk terus belajar. Sebagian lagi menyebutkan hanya menggunakan metode teks book.

3. Bagaimana pembelajaran yang berkualitas. Sebagian tutor menjawab bahwa pembelajaran yang berkualitas adalah pembelajaran itu bermanfaat bagi warga belajar. Sebagian tutor tidak memberikan argumen dengan alasan tutor baru belum berpengalaman.

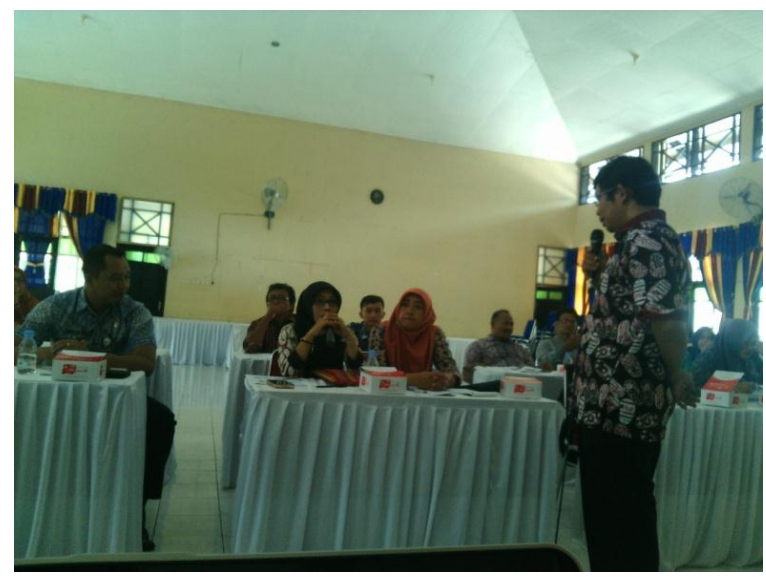

Gambar 2. Kegiatan tanya jawab

Dari proses tanya jawab tersebut menunjukkan bahwa peserta pelatihan sangat antusias dan termotivasi untuk mengikuti kegiatan pelatihan. Para tutor tidak merasa malu untuk menyampaikan pendapat tentang pengalaman yang mereka miliki selama melakukan pembelajaran meskipun yang mereka sampaikan belum sesuai dengan metode pembelajaran yang inovatif. Kegiatan terakhir yaitu penutup, kegiatan penutupan dilakukan oleh ketua SKB Wonogiri dilanjutkan dengan foto bersama antara pengabdi, pihak SKB dan peserta pelatihan.
Kegiatan pelatihan metode pembelajaran inovatif memberikan manfaat yang berarti bagi tutor keaksaraan. Hal ini dikarenakan kegiatan pembelajaran yang selama ini dilakukan oleh tutor belum menggunakan metode pembelajaran inovatif secara maksimal. Selain itu kegiatan ini mampu menjawab permasalahan yang selama ini dihadapi oleh tutor dalam pelaksanaan pembelajaran. Permasalahan yang sering dialami yaitu tingkat motivasi warga belajar keaksaraan yang rendah yang dibuktikan dengan kehadiran warga belajar yang semakin menurun dari 10 warga belajar menjadi 3 warga belajar.

Permasalahan tersebut telah diberikan solusi oleh pemateri yaitu seorang tutor harus memiliki kesan yang baik sehingga warga belajar terus merasa butuh untuk belajar. Tutor tidak boleh merasa paling bisa dalam artian tidak menganggap bahwa warga belajar itu memiliki pengalaman yang cukup banyak untuk dijadikan sumber pembelajaran. Dalam hal ini proses pembelajaran harus berpusat pada warga belajar bukan kepada tutor. Metode pembelajaran inovatif sering diakronimkan PAKEM yaitu Pembelajaran Aktif Kreatif Efektif dan Menyenangkan. Apabila tutor mampu mengaplikasikan metode ini maka warga belajar akan selalu termotivasi untuk terus belajar. Dapat dijelaskan bahwa pembelajaran yang berkualitas yaitu pembelajaran yang menyenangkan, menantang, mendorong bereksplorasi, memberikan pengalaman sukses, dan memberikan kecakapan berpikir. Tutor memiliki peran penting dalam mensukseskan proses pembelajaran. dalam hal ini tutor yang berkualitas yaitu tutor yang mampu mengembangkan kegiatan pembelajaran dengan menarik dan beragam, mampu membuat alat bantu belajar, mampu memanfaatkan lingkungan sebagai sumber belajar, mampu mengelola kelas dan sumber belajar dengan baik, mampu merencanakan proses dan sumber belajar.

Masalah yang dihadapi tutor selain motivasi warga belajar adalah keterbatasan dalam mnggunakan alat/media untuk menjelaskan materi. Perlu dipahami bahwa 
warga belajar keaksaraan adalah orang dewasa, sehingga mereka tentunya sudah memiliki pengalaman dan pekerjaan masingmasing. Dalam hal ini alat/media pembelajaran dapat berasal dari kehidupan mereka. Sebagai contoh apabila warga belajarnya adalah ibu rumah tangga, media yang digunakan bisa berasal dari peralatan rumah tangga seperti panci, sutil, wajan dan lain-lain. Selain itu media pembelajaran dapat diambilkan dari macam-macam bumbu dapur misalnya : jahe, kencur, garam, cabai, dan lain-lain. Hal ini dilakukan karena warga belajar sudah akrab dengan alat-alat dan bahan-bahan tersebut. Untuk memberikan pengalaman yang berarti maka alat-alat dan bahan-bahan tersebut dibawa sendiri oleh warga belajar dengan pembagian tugas setiap warga belajar.

Penjelasan-penjelasan yang sudah disampaikan pemateri telah memberikan banyak pengetahuan untuk merubah metode pembelajaran yang sebelumnya kurang menyenangkan. Dalam proses pelatihan terhadap tutor perlu diperhatikan hal-hal sebagai berikut agar materi yang disampaikan dapat diterima secara maksimal:

\section{a. Pengalaman peserta pelatihan}

Peserta pelatihan adalah tutor keaksaraan di kabupaten Wonogiri yang merupakan orang dewasa dan sudah memiliki pengalaman yang cukup banyak dalam proses pembelajaran. meskipun ada beberapa tutor yang masih tergolong baru. Namun demikian pengalaman belajar orang dewasa merupakan sumber pengetahuan sehingga dalam proses pelatihan perlu memperhatikan pengalaman mereka. Pengalaman yang mereka sampaikan yaitu memberikan keterampilan kepada warga belajar selain memberikan teori, akan tetapi warga belajar lebih senang dengan keterampilan dengan tidak mengikuti kegiatan teori. Melalui pelatihan metode pembelajaran inovatif ini perserta memahami bahwa keterampilan yang diberikan disesuaikan teori yang disampaikan juga, sehingga ada fungsionalisme dalam kehidupan warga belajar dan warga belajar merasa termotivasi untuk belajar.

\section{b. Sarana prasarana pelatihan}

Sarana prasarana merupakan unsur penting yang harus ada dalam kegiatan pelatihan seperti gedung, tempat duduk, mikrofon, layar LCD, laptop dan modul. Modul yang diberikan kepada peserta pelatihan harus sesuai dengan apa yang disampaikan oleh pemateri dan setiap peserta pelatihan harus mendapatkannya. Mikrofon sebagai pengeras susara tidak hanya satu agar tidak menganggu dalam proses tanya jawab dan diskusi.

\section{c. Motivasi peserta pelatihan}

Motivasi merupakan hal yang penting yang harus hadir dalam diri peserta pelatihan. Kegiatan pelatihan yang bersifat ceramah hanya akan memberikan kesan membosankan bagi peserta pelatihan. Oleh karena itu perlu adanya pemutaran video atau ice breaking untuk menumbuhkan suasana belajar. diharapkan setelah kegiatan pelatihan berakhir peserta memiliki motivasi yang tinggi untuk menerapkan hasil belajar.

Kegiatan pelatihan metode pembelajaran inovatif telah memberikan manfaat yaitu peserta memahami metode pembelajaran yang inovatif (PAKEM). Perserta pelatihan juga memahami cara mengkondisikan warga belajar dengan tingkat kehadiran rendah. Peserta pelatihan memahami penggunaan media pembelajaran yang murah. Rencana aksi yang akan mereka lakukan adalah menerapkan pengetahuan dari pelatihan yang sudah terima dalam kegiatan pembelajaran keaksaraan.

\section{Melakukan Evaluasi}

Evaluasi dalam kegiatan pelatihan metode pembelajaran inovatif ini dilakukan ketika proses penyajian materi selesai yaitu melalui tanya jawab. Peserta pelatihan menjelaskan bahwa pelatihan ini sangat bermanfaat dan merupakan materi baru bagi mereka. Peserta memahami tentang metode PAKEM (Pembelajaran Aktif Kreatif dan Menyenangkan) di mana selama ini belum pernah mereka terapkan dalam kegiatan pembelajaran keaksaraan. Dengan demikian 
dapat disimpulkan bahwa kegiatan pelatihan metode pembelajaran inovatif bagi tutor keaksaraan telah berhasil dengan tingkat ketercapaian :

a. Semua peserta hadir dalam kegiatan pelatihan metode pembelajaran inovatif dari awal sampai kahir.

b. Peserta pelatihan memahami metode pembelajaran inovatif

c. Peserta pelatihan mampu mempraktekkan metode pembelajaran inovatif dalam kelompok keaksaraan di masyarakat.

Faktor Pendukung dan Faktor Penghambat

Faktor pendukung dalam kegiatan pelatihan metode pembelajaran inovatif ini adalah 1) motivasi peserta pelatihan yang mampu mengikuti kegiatan dari awal sampai akhir, 2) motivasi dan kekompakan tim pengabdi dalam melakukan pengabdian, dan 3) sarana-prasarana yang mencukupi untuk berlangsungnya kegiatan pelatihan.

Sedangkan untuk faktor penghambat kegiatan pelatihan adalah terkendala waktu pelaksanaan PPM. Kegiatan PPM direncanakan pukul o9.oo tetapi dimulai pukul 10.oo. Untuk mengatasi hal tersebut tim pengabdi melakukan komunikasi dengan kelompok sasaran terkait keterlambatan dan waktu pelaksanaan kegiatan PPM akan diperpanjang dari waktu yang sebelumnya sudah disepakati bersama.

\section{SIMPULAN}

Kegiatan pelatihan metode pembelajaran inovatif dapat berjalan dengan lancar sesuai perencanaan. Peserta pelatihan memiliki pengetahuan dalam pembelajaran inovatif yaitu metode PAKEM dan pembelajaran berpusat pada warga belajar. Selain itu peserta pelatihan mampu mempraktekkan metode pembelajaran inovatif dalam pembelajaran di masyarakat

\section{DAFTAR PUSTAKA}

Dwi Darmanto. (2010). Model Pemberdayaan Perempuan Melalui Kejar KF. Surabaya:BPPLSP Regional VI Surabaya

Sujarwo dan Lutfi Wibawa. (2013). Analisis Page | 51 Permasalahan Perempuan dan Potensi Lokal. Laporan Penelitian. Yogyakarta, Fakultas Ilmu Pendidikan UNY (Laporan Penelitian Tidak Dipublikasikan)

Sujarwo,dkk.(2015). Pengembangan Model Pemberdayaan Perempuan Desa Wisata Melalui Pendidikan Berbasis Komunitas di Desa Wisata Bejiharjo Kecamatan Karangmojo Kabupaten Gunungkidul. Laporan Penelitian. Yogyakarta, Fakultas Ilmu Pendidikan UNY (Laporan Tidak Dipublikasikan)

\section{PROFIL SINGKAT}

Penulis pertama Tristanti, lahir di Purworejo pada tanggal 8 Juli 1989. Pendidikan SI di Universitas Negeri Yogyakarta Jurusan pendidikan Luar Sekolah dan lulus pada tahun 2011. Kemudian melanjutkan Program Pascasarjana di Universitas Negeri Yogyakarta pada jurusan Pendidikan Luar Sekolah dan lulus pada tahun 2013. Saat ini bekerja sebagai dosen di jurusan Pendidikan Luar Sekolah UNY.

Penulis kedua Sujarwo, lahir di Karanganyar pada tanggal 30 Oktober 1969. Pendidikan SI pada jurusan pendidikan Luar Sekolah dan lullus tahun 1995. Kemudian melanjutkan program Pascasarjanan pada jurusan teknologi Pendidikan dan lulus pada tahun 2002. Pendidikan terakhir adalah $\mathrm{S}_{3}$ dengan jurusan Teknologi Pembelajaran pada tahun 2011. Saat ini bekerja sebagai dosen PLS di Universitas Negeri Yogyakarta.

Penulis ketiga adalah RB. Suharta, lahir di Bantul pada tanggal 16 April 196o. Pendidikan SI di IKIP Yogyakarta pada jurusan Pendidikan Lluar Sekolah dan lulus pada tahun 1984. Kemudian melanjutkan pendidikan S2 pada jurusan Pendidikan Luar Sekolah di IKIP Malang dan lulus pada tahun 1996. Saat ini bekerja sebagai dosen PLS di Universitas Negeri Yogyakarta. Penulis 


\section{Journal of Millennial Community, 2 (2), September 2020 \\ Tristanti, Sujarwo, RB Suharta}

kedua Nasrah Natsir, lahir di Polman pada tanggal 3 Februari 1986. Pendidikan S1 di Universitas Negeri Makassar Jurusan Pendidikan Luar Sekolah dan lulus pada tahun 2009. Pada tahun 2010 melanjutkan pendidikan S2 di Universitas Negeri
Yogyakarta Jurusan Pendidikan Luar Sekolah dan lulus pada tahun 2012. Pekerjaan sebagai dosen di Jurusan Pendidikan Luar Sekolah Fakultas Ilmu Pendidikan Universitas Negeri Makassar. 